\title{
Anthraquinone G503 Induces Apoptosis in Gastric Cancer Cells through the Mitochondrial Pathway
}

\author{
Lijun Huang ${ }^{19}$, Ting Zhang ${ }^{19}$, Shuai $\mathrm{Li}^{1}$, Junting Duan ${ }^{1}$, Fang $\mathrm{Ye}^{1}$, Hanxiang $\mathrm{Li}^{2}$, Zhigang She ${ }^{2}$, \\ Guoquan $\mathrm{GaO}^{1,3 *}$, Xia Yang ${ }^{1,2 *}$
}

1 Department of Biochemistry, Zhongshan School of Medicine, Sun Yat-sen University, Guangzhou, Guangdong Province, China, 2 Key Laboratory of Functional Molecules from Marine Microorganisms (Sun Yat-sen University), Department of Education of Guangdong Province, Guangzhou, Guangdong Province, China, $\mathbf{3}$ China Key Laboratory of Tropical Disease Control (Sun Yat-sen University), Ministry of Education, Guangzhou, Guangdong Province, China

\begin{abstract}
G503 is an anthraquinone compound isolated from the secondary metabolites of a mangrove endophytic fungus from the South China Sea. The present study elucidates the anti-tumor activity and the underlying mechanism of G503. Cell viability assay performed in nine cancer cell lines and two normal cell lines demonstrated that the gastric cancer cell line SGC7901 is the most G503-sensitive cancer cells. G503 induced SGC7901 cell death via apoptosis. G503 exposure activated caspases-3, 8 and -9. Pretreatment with the pan-caspase inhibitor Z-VAD-FMK and caspase-9 inhibitor Z-LEHD-FMK, but not caspase-8 inbibitor Z-IETD-FMK, attenuated the effect of G503. These results suggested that the intrinsic mitochondrial apoptosis pathway, rather than the extrinsic pathway, was involved in G503-induced apoptosis. Furthermore, G503 increased the ratio of $\mathrm{Bax}$ to $\mathrm{Bcl}-2$ in the mitochondria and decreased the ratio in the cytosol. G503 treatment resulted in mitochondrial depolarization, cytochrome $c$ release and the subsequent cleavage of caspase -9 and -3 . Moreover, it is reported that the endoplasmic reticulum apoptosis pathway may also be activated by G503 by inducing capase-4 cleavage. In consideration of the lower $50 \%$ inhibitory concentration for gastric cancer cells, G503 may serve as a promising candidate for gastric cancer chemotherapy.
\end{abstract}

Citation: Huang L, Zhang T, Li S, Duan J, Ye F, et al. (2014) Anthraquinone G503 Induces Apoptosis in Gastric Cancer Cells through the Mitochondrial Pathway. PLoS ONE 9(9): e108286. doi:10.1371/journal.pone.0108286

Editor: Javier S. Castresana, University of Navarra, Spain

Received April 19, 2014; Accepted August 19, 2014; Published September 30, 2014

Copyright: (c) 2014 Huang et al. This is an open-access article distributed under the terms of the Creative Commons Attribution License, which permits unrestricted use, distribution, and reproduction in any medium, provided the original author and source are credited.

Data Availability: The authors confirm that all data underlying the findings are fully available without restriction. All relevant data are within the paper and its Supporting Information files.

Funding: This study was supported by National Nature Science Foundation of China, Grant Number: 30973449, 81172163, 81272515, 81272338, 81200706; National Key Sci-Tech Special Project of China, Grant Number: 2009ZX09103-642, 2013ZX09102053; Program for Doctoral Station in University, Grant Number: 20120171110053, 20130171110053; Key Project of Nature Science Foundation of Guangdong Province, China, Grant Number: 10251008901000009; Key Sci-tech Research Project of Guangdong Province, China, Grant Number: 2011B031200006; Guandong Natural Science Fund, Grant Number: S2012010009250, S2012040006986; Key Sci-tech Research Project of Guangzhou Municipality, China, Grant Number: 2011Y1-00017-8, 12A52061519; Program for Young Teacher in University, Grant Number: 10YKPY28; Changjiang Scholars and Innovative Research Team in University, number: 985 project PCSIRT 0947. The funders had no role in study design, data collection and analysis, decision to publish, or preparation of the manuscript.

Competing Interests: The authors have declared that no competing interests exist.

*Email: yangxia@mail.sysu.edu.cn (XY); gaogq@mail.sysu.edu.cn (GG)

9 These authors contributed equally to this work.

\section{Introduction}

Surgery, radiotherapy and chemotherapy are the primary clinical tumor treatments. However, surgery and radiotherapy are ineffective in metastatic cancer; if chemotherapy is used properly, metastasis may be inhibited [1]. With regard to anticancer drug development, anthracyclines are the most effective anti-cancer drugs [2]. Natural products from oceans are important sources of novel anti-cancer drugs [3]. Marine microorganism metabolites with unique structures and pharmacological activities are typically used as leading antitumor compounds [4]. Anthraquinone compounds, such as daunorubicin, doxorubicin, epirubicin and mitoxantrone, are the most effective clinical anti-cancer drugs [2]. The marine anthraquinone SZ-685C suppresses the proliferation of human breast cancer [5-6] and human nasopharyngeal carcinoma (NPC) cells [7]. Huang et al. demonstrated that anthraquinones from rhubarb, such as emodin, aloe-emodin and rhein, inhibit the growth and proliferation of various cancer cells, such as lung adenocarcinoma, myelogenous leukemia, neuroblastoma, hepatocellular carcinoma, bladder cancer and others [8].

The mechanism of the antitumor activity of anthraquinones is primarily involved in the following aspects [9-10]: DNA interactions through binding, intercalating and interfering separation of the DNA double strand; direct membrane effects; DNA damage in response to topoisomerase II inhibition or the generation of free radicals, such as reactive oxygen species (ROS), and the induction of apoptosis via topoisomerase II inhibition, functional p53 or ROS generation. In addition, anthraquinones also trigger apoptosis through the JNK(c-Jun Nterminal kinase) [11], Akt/PKB (Protein Kinase B) [5,12] and mitochondrial pathways [13-14].

G503 is an anthraquinone compound isolated from the secondary metabolites of the mangrove endophytic fungus No. 1403 from the South China Sea [15].However, whether G503 possesses anticancer potential as an anthraquinone compound has not been investigated. Therefore, the present study was 
Table 1. $I C_{50}$ values of $\mathrm{G} 503$ on cancer cell lines and normal cell lines.

\begin{tabular}{ll}
\hline & \\
\hline Cell line & IC $_{\mathbf{5 0}}(\boldsymbol{\mu \mathbf { m o l }} / \mathbf{L})$ \\
\hline HONE-1 & 35.7 \\
CNE-2 & 35.6 \\
$5-8 \mathrm{~F}$ & 31.7 \\
A549 & 20.0 \\
HepG2 & 13.3 \\
B7402 & 19.8 \\
Rb & 44.0 \\
PC3 & 21.1 \\
SGC7901 & 10.24 \\
HUVEC & 22.4 \\
Chang liver cells & 17.5 \\
\hline doi:10.1371/journal.pone.0108286.t001 &
\end{tabular}

designed to elucidate the anti-tumor activity of G503 and the underlying mechanism involved.

\section{Materials and Methods}

\section{Chemicals and Reagents}

3-(4,5-dimethylthiazol-2-yl)-2,5-diphenylterazolium bromide (MTT) and ROS scavenger N-acetyl-cysteine (NAG) were purchased from Sigma-Aldrich (St. Louis, MO, USA). Hochest 33342, carboxy-H2DCFDA, MitoProbe DiOC2 (3) Assay Kit and MitoProbe Transition Pore Assay Kit (M34153) were obtained from Invitrogen (USA). Annexin V-FITC (fluorescein isothiocyanate)/PI (propidium iodide) Apoptosis Detection Kit was purchased from Keygen (Nanjing, Jiangsu, CHINA). RPMI1640 medium and fetal bovine serum (FBS) were from Hyclon (Logan, UT, USA). Caspase-8 inhibitor Z-IETD-FMK, caspase-9 inhibitor Z-LEHD-FMK and caspase-family inhibitor Z-VAD-FMK were from Calbiochem (Gibbstown, NJ, USA) and Beyotime (CHINA). Antibodies against caspase-3, caspase-4, caspase-8, caspase-9 and COXIV antibody were from Cell Signaling Technology (Beverly, MA, USA). Antibodies against cytochrome $c$, Bax, Bcl-2, p38, p-p38 and anti-goat LgG-HRP were from Santa Cruz Biotechnology (Santa Cruz, CA, USA). Mouse anti- $\beta$ actin and anti-GAPDH primary antibodywere from SigmaAldrich (St. Louis, MO, USA). Anti-rabbit LgG-peroxidase and anti-mouse IgG-peroxidase were from Vector (Burlingame, CA, USA).Mitochondria isolation kit was purchased from Pierce (Pierce, IL, USA), protein assay kit were purchased from BioRad (Hercules, CA, USA), and the ECL detection kit were from Applygen Technologies Inc (Beijing, CHINA).

\section{Fermentation, extraction and isolation of G503 from Nigrosporasp. No. 1403}

NO.1403 was isolated from decayed wood of Kandeliacandel (L.) Druce and reidentified as Nigrospora sp. (Genebank accession number: HQ891110), collected from Mai Po, Hong Kong, and a salt lake in the Bahamas. G503 was isolated and purified from the secondary metabolites of NO. 1403 [15]. Starter cultures were maintained on cornmeal seawater agar. Plugs of agar supporting mycelial growth were cut and transferred aseptically to a $250 \mathrm{~mL}$ Erlenmeyer flask containing $100 \mathrm{~mL}$ of liquid medium (glucose $10 \mathrm{~g} / \mathrm{L}$, peptone $2 \mathrm{~g} / \mathrm{L}$, yeast extract $1 \mathrm{~g} / \mathrm{L}, \mathrm{NaCl}_{2} \mathrm{~g} / \mathrm{L}, \mathrm{pH} \mathrm{D}$ 7.0). The flask was incubated at $28^{\circ} \mathrm{C}$. After shaking on a rotary shaker for 3-5 days, the mycelium was aseptically transferred to a $500 \mathrm{ml}$ Erlenmeyer flask containing the culture liquid $(200 \mathrm{~mL})$. The flask was then incubated at $28^{\circ} \mathrm{C}$ for 25 days.

The cultures $(150 \mathrm{~L})$ were filtered through cheesecloth. The filtrate was concentrated to $5 \mathrm{~L}$ below $50^{\circ} \mathrm{C}$ and extracted three times by shaking with an equal volume of ethyl acetate. The combined organic extracts were subjected to a silica gel column, and eluted with a gradient of petroleum ether to ethyl acetate to yield the compound.

The compound was dissolved in dimethyl sulfoxide (DMSO) at a stock concentration of $50 \mathrm{mmol} / \mathrm{L}$ and diluted to specific concentrations prior to use.

\section{Cell culture}

HUVECs were isolated from the human umbilical vein cords of normal parturitions and cultured following a protocol described previously [16-17]. Chang liver cells and tumor cell lines HONE1, GNE-2, 5-8F, HepG2, B7402, Rb, PC3, A549 and SGC7901, AGS were maintained by our laboratory and cultured in RPMI1640 medium supplemented with $10 \%$ FBS, $100 \mathrm{U} / \mathrm{mL}$ streptomycin and $100 \mathrm{U} / \mathrm{mL}$ penicillin (Gibco) at $37^{\circ} \mathrm{C}$ in a humidified atmosphere of $5 \% \mathrm{CO}_{2}$. This study conforms to the principles outlined in the Declaration of Helsinki, approved by the Medical Ethics Committee of Sun Yat-Sen University, and written informed consent was obtained from the donor.

\section{Cell viability assay}

Cells were seeded at a density of $2 \times 10^{4}$ cells $/ \mathrm{mL}$ in 24-well plates (HUVECs were seeded in gelatin-coated 24-well plates). When the cells achieved a density of $60 \%-70 \%$, they were treated with various concentrations of G503 for $48 \mathrm{~h}$ in RPMI 1640 medium ( $1 \mathrm{~mL} /$ well) without $\mathrm{FBS}$; the negative control groups were treated with PBS. Subsequently, $100 \mu \mathrm{L}$ MTT $(5 \mathrm{mg} / \mathrm{mL})$ dissolved in PBS was added to each well and incubated for an additional $4 \mathrm{~h}$ to allow for the formation of formazancrystals. The crystals were solubilized in $1 \mathrm{~mL}$ DMSO in each well. The optical density (OD) values of the purple solution that represented cell viability were measured at 570nm [18-19]. After three independent experiments, cell survival was calculated using the following formula: survival $(\%)=($ mean experimental OD value $/$ mean control OD value) $\times 100 \%$. The values were expressed as the $50 \%$ inhibitory concentration $\left(\mathrm{IC}_{50}\right)$, which was calculated by the regression method in the linear range. 
A
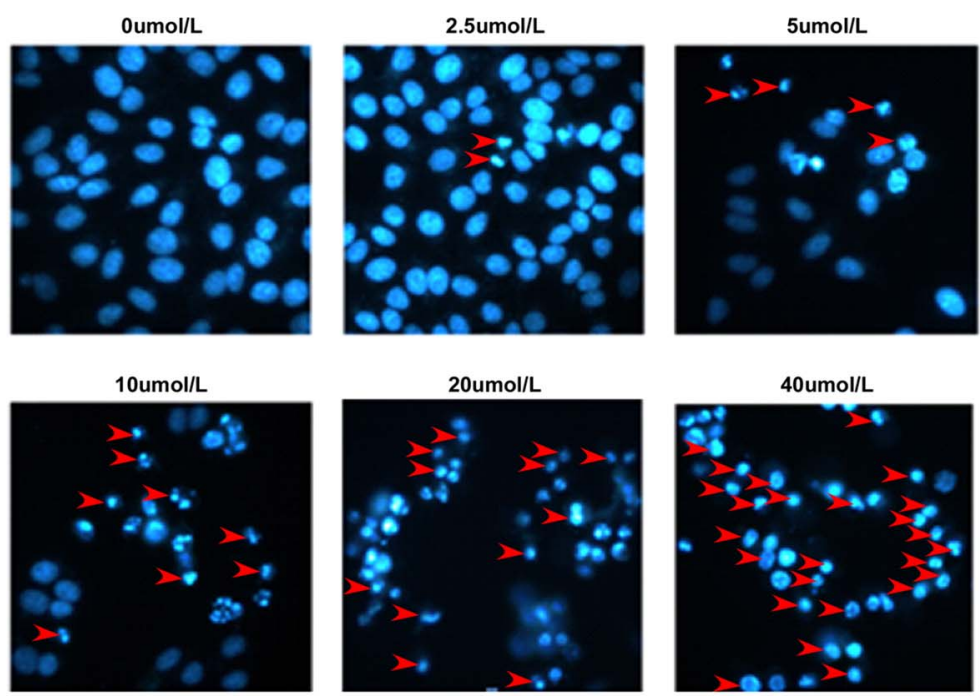

B
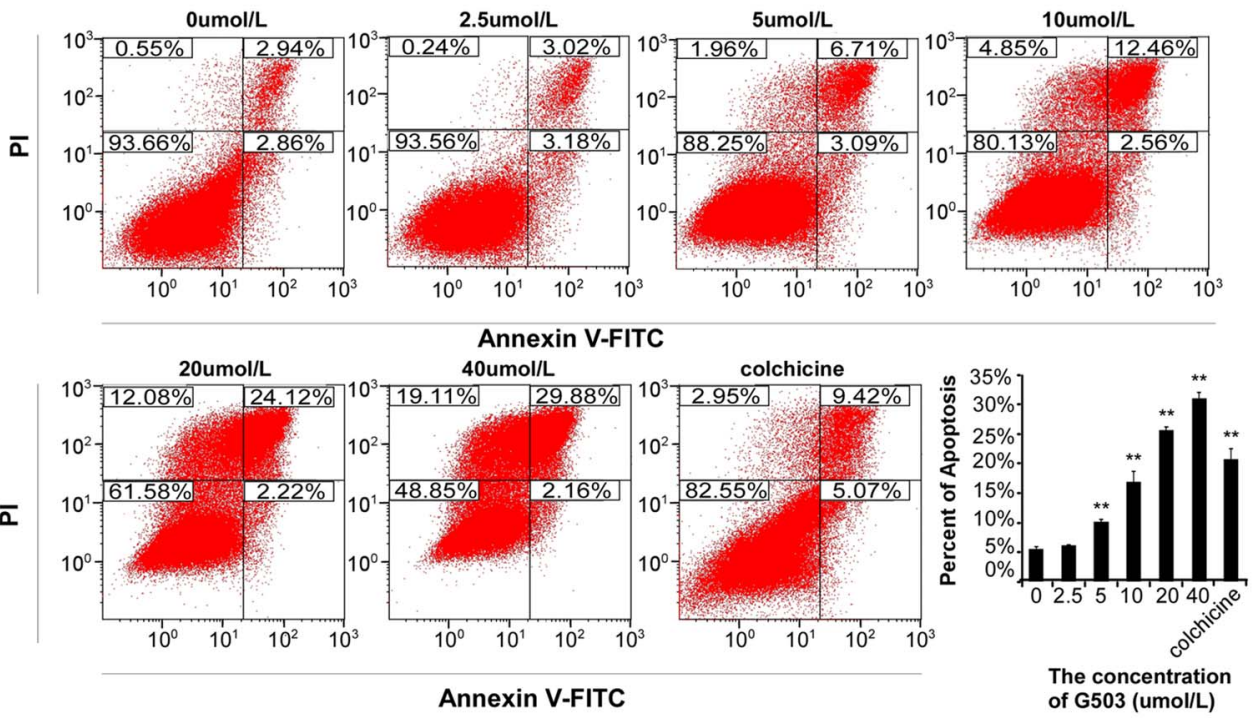

C
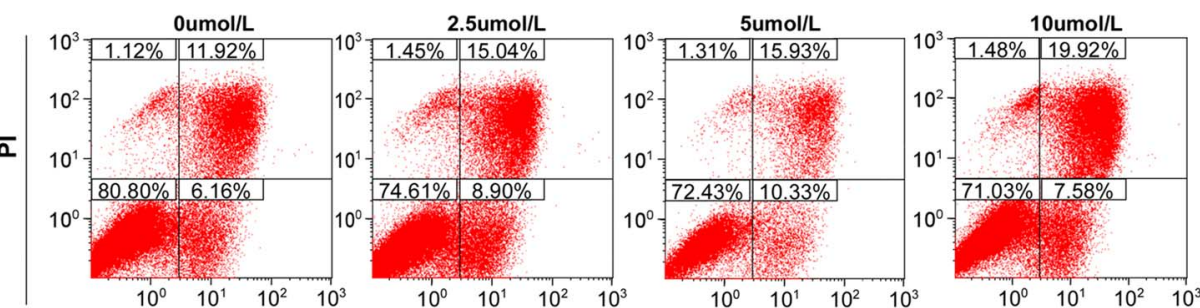

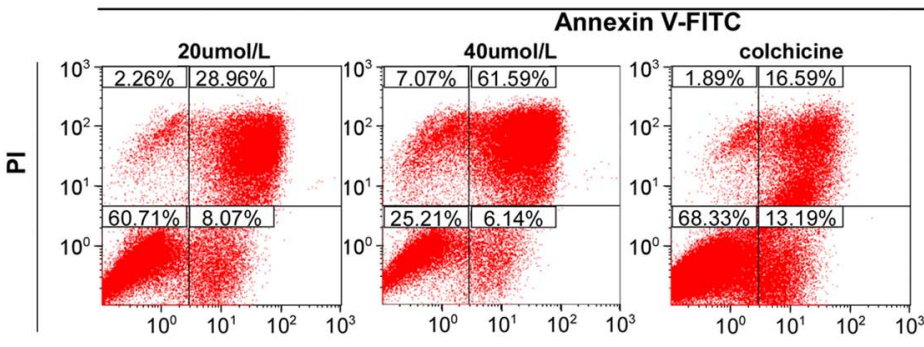

Annexin V-FITC

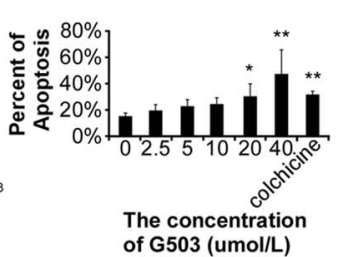


Figure 1. The effects of various G503 concentrations on gastric cancer cell apoptosis. (A) SGC7901 cells were treated with various G503 concentrations $(0-40 \mu \mathrm{mol} / \mathrm{L})$ for $24 \mathrm{~h}$ and stained with Hoechst 33342. Red arrows indicate the apoptotic cells. (B), (C) SGC7901 cells (B) and AGS cells (C) were analyzed by flow cytometry after treatment with various G503 concentrations- for $24 \mathrm{~h}$. For the quantitative analysis of G503-induced SGC7901 and AGS cell apoptosis, all data are presented as the mean \pm SD of three independent experiments. ${ }^{*}$ and ${ }^{* *}$ represent $P<0.05$ and $P<0.01$, respectively.

doi:10.1371/journal.pone.0108286.g001

\section{Hoechst 33342 staining assay}

SGC7901 cells were plated in 6-well plates at a density of $10^{5}$ cells per well and treated with G503 concentrations ranging from $0 \mu \mathrm{mol} / \mathrm{L}$ to $40 \mu \mathrm{mol} / \mathrm{L}$ for $24 \mathrm{~h}$. The cells were labeled with
$10 \mu \mathrm{g} / \mathrm{mL}$ Hoechst $33342[20]$ for $10 \mathrm{~min}$ at $37^{\circ} \mathrm{C}$ and observed using fluorescence microscopy (Olympus X71-A12FL/PH).
A



B

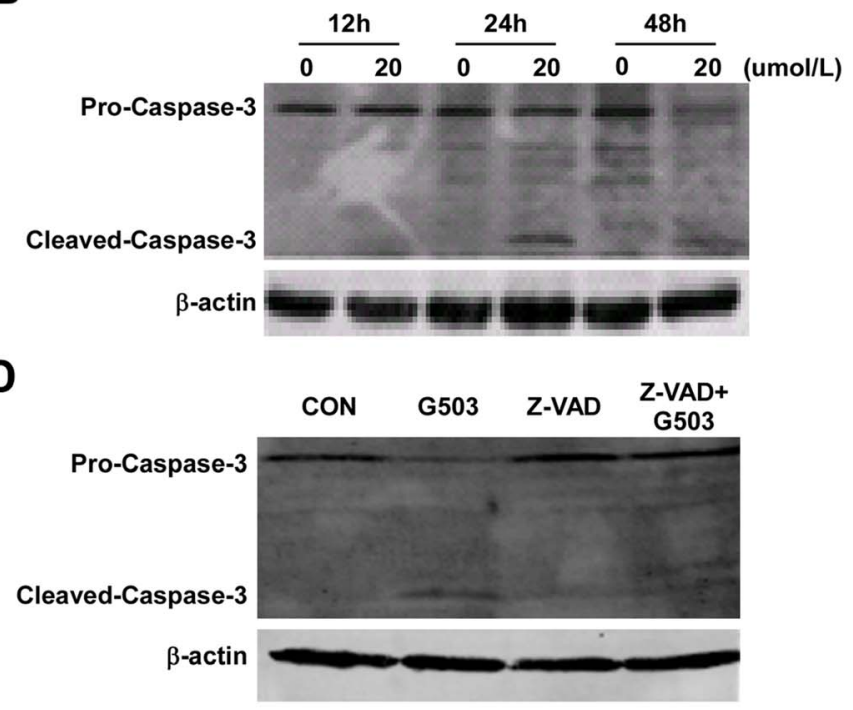

E
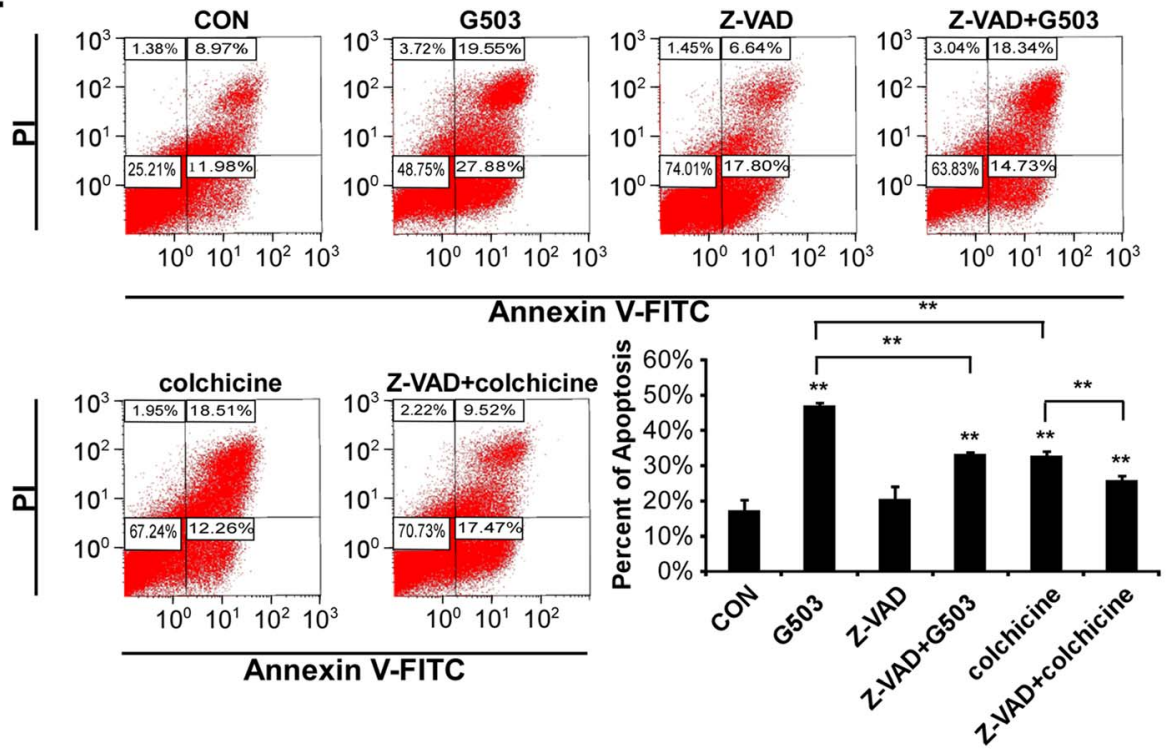

Figure 2. The effects of G503 and Z-VAD-FMK on caspase activation and apoptosis in SGC7901 cells. (A),(B) Cells were treated with various G503 concentrations for $24 \mathrm{~h}$ (A) and treated with $20 \mu \mathrm{mol} / \mathrm{L}$ G503 for various time (B). All celluar proteins were extracted and caspase-3 protein levels were analyzed by Western blotting. (C)-(E) Cells were pre-incubated with Z-VAD-FMK for 30 min before treated with $20 \mu \mathrm{mol} / \mathrm{L}$ G503 for $24 \mathrm{~h}$. All celluar proteins were extracted and caspase-9 (C), -3 (D) protein levels were analyzed by Western blotting. The cellular apoptotic rates were determined by flow cytometry (E). All values are displayed as the mean \pm SD of at least three independent experiments $\left({ }^{*} P<0.05\right.$, ${ }^{* *} P<0.01$ vs. control).

doi:10.1371/journal.pone.0108286.g002 
A

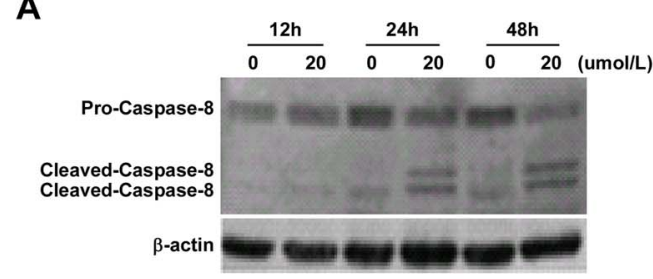

B

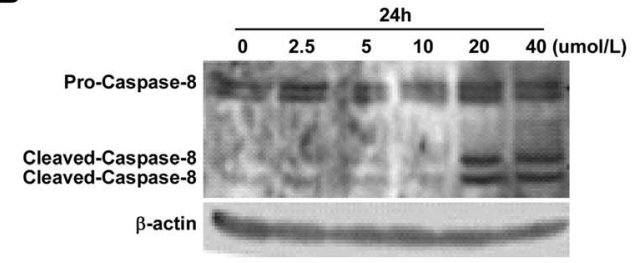

C

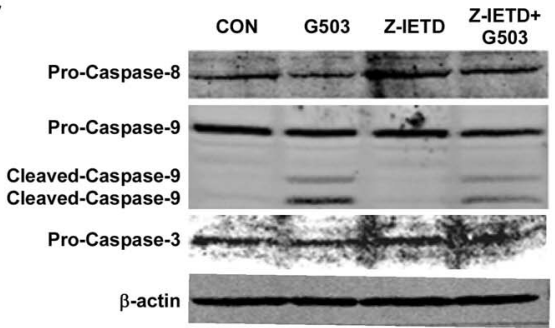

D
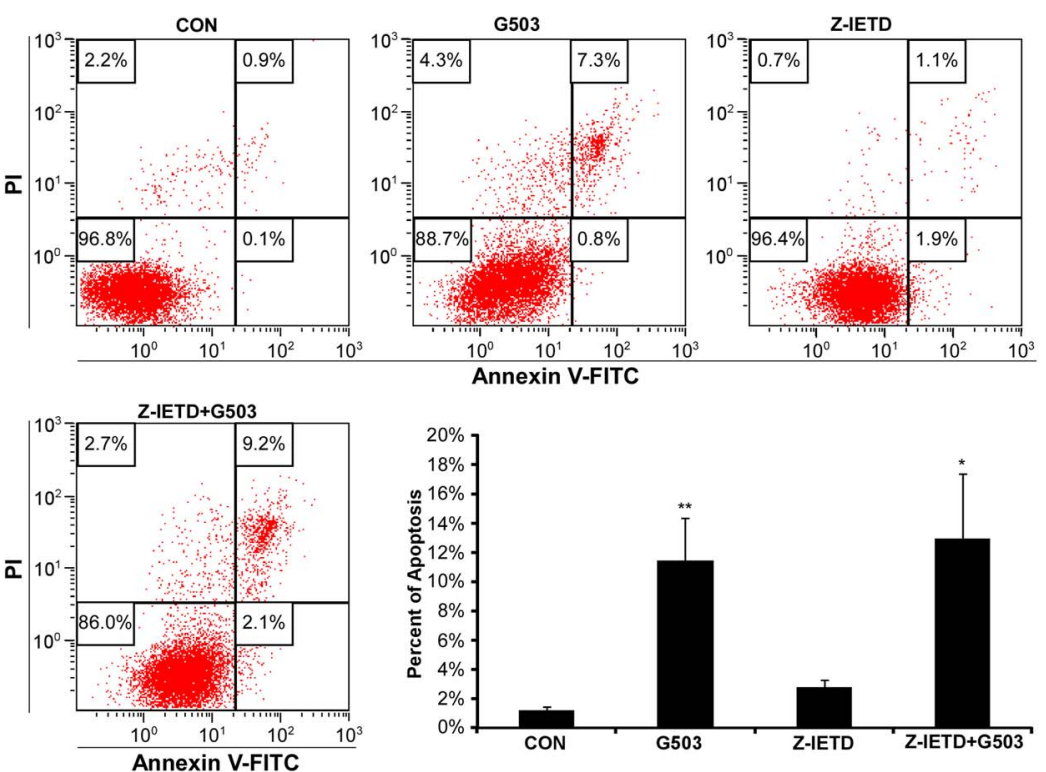

Figure 3. The effects of G503 and Z-IETD-FMK on caspase activation and apoptosis in SGC7901 cells. (A), (B) Cells were treated with $20 \mu \mathrm{mol} / \mathrm{L}$ G503 for various times (A) and treated with various $\mathrm{G} 503$ concentrations $(0-40 \mu \mathrm{mol} / \mathrm{L})$ for $24 \mathrm{~h}(\mathrm{~B})$. The cellular total proteins were extracted to detect the levels of caspase- 8 by Western blotting. (C), (D) Cells were pre-incubated with $20 \mu \mathrm{mol} / \mathrm{L}$ Z-IETD-FMK for $30 \mathrm{~min}$ and subsequently treated with $20 \mu \mathrm{mol} / \mathrm{L} \mathrm{G503}$ for $24 \mathrm{~h}$. The cellular proteins were extracted to detect the levels of caspase $-8,-9$ and -3 by Western blotting (C). The cellular apoptotic rates were determined by flow cytometry (D). All values are presented as the mean \pm SD of at least three independent experiments $\left({ }^{*} P<0.05, * * P<0.01\right.$ vs. control).

doi:10.1371/journal.pone.0108286.g003

\section{Annexin V-FITC/PI staining assay}

SGG7901 cells were collected at a density of $5 \times 10^{5}$ to $5 \times 10^{6} /$ $\mathrm{mL}$ after G503 treatment at concentrations ranging from $0 \mu \mathrm{mol} /$ $\mathrm{L}$ to $40 \mu \mathrm{mol} / \mathrm{L}$ for $24 \mathrm{~h}$ in 6 -well plates; cells treated with $25 \mu \mathrm{mol} / \mathrm{L}$ colchicine were used as positive control. The cells were then washed and stained according to the manufacturer's instructions (Annexin V-FITC/PI Apoptosis Detection Kit). Briefly, the cells were resuspended in $500 \mu \mathrm{L} 1 \times$ binding buffer. Next, $5 \mu \mathrm{L}$ AnnexinV-FITC and $5 \mu \mathrm{L} 20 \mu \mathrm{g} / \mathrm{mL}$ PI was added to the sample and incubated at room temperature for $15 \mathrm{~min}$ in the dark. The stained samples were then assessed by flow cytometry (Becton Dickinson, NJ, USA) to identify apoptotic cells.

\section{Determination of mitochondrial membrane potential}

SGG7901 cells were plated in 6-well plates. Upon achieving a density of $60 \%$, the cells were treated with $20 \mu \mathrm{mol} / \mathrm{L}$ G503 for $18 \mathrm{~h}$ and then collected to assess the mitochondrial membrane potential according to the manufacturer's recommendations(MitoProbe DiOC2 (3) Assay Kit). Briefly, $1 \times 10^{6} / \mathrm{mL}$ cells were resuspended in $37^{\circ} \mathrm{C}$ PBS. The positive control groups were pretreated with $1 \mu \mathrm{L}$ of $50 \mathrm{mmol} / \mathrm{L} \mathrm{CGCP}$ at $37^{\circ} \mathrm{C}$ for $5 \mathrm{~min}$. All of the groups were then treated with $5 \mu \mathrm{L}$ of $10 \mu \mathrm{mol} / \mathrm{L} \mathrm{DiOC}_{2}$ (3) for $30 \mathrm{~min}$ at $37^{\circ} \mathrm{C}$ and assessed by flow cytometry. The mitochondrial membrane potential was calculated based on the following equation: mitochondrial membrane potential $=(\mathrm{red}$ fluorescence intensity)/(green fluorescence intensity).

\section{Detection the opening of mitochondria Permeability Transition Pore (mPTP)}

SGC7901 cells were plated in 6-well plates. Upon achieving a density of $60 \%$, the cells were treated with $20 \mu \mathrm{mol} / \mathrm{L} \mathrm{G} 503$ for $18 \mathrm{~h}$ and collected to assess mPTP opening by flow cytometry (Becton Dickinson, NJ, USA) according to the manufacturer's protocol (MitoProbe Transition Pore Assay Kit). Briefly, each sample was divided into 3 aliquots and treated as follows: aliquot 1 was treated with $5 \mu \mathrm{L} 2 \mu \mathrm{mol} / \mathrm{L}$ Calcein $\mathrm{AM}$ in the dark; aliquot 2 was treated with $5 \mu \mathrm{L}$ Calcein $\mathrm{AM}$ and $5 \mu \mathrm{L} 80 \mathrm{mmol} / \mathrm{L} \mathrm{CoCl}_{2}$ in the dark; and aliquot 3 was treated with $5 \mu \mathrm{L}$ Calcein AM, $5 \mu \mathrm{L} \mathrm{CoCl}{ }_{2}$ and $5 \mu \mathrm{L}$ of $100 \mu \mathrm{mol} / \mathrm{L}$ ionomycin. The aliquots were then incubated at $37^{\circ} \mathrm{C}$ for $15 \mathrm{~min}$ in the dark. After being washed with $\mathrm{HBSS} / \mathrm{Ca}^{2+}$ and re-suspended in $400 \mu \mathrm{L}$ HBSS/ $\mathrm{Ca}^{2+}$, the cells were assessed by flow cytometry within $1 \mathrm{~h}$. The mPTP opening condition is calculated as follows: (fluorescence of aliquot 2- the fluorescence of aliquot 3)/(the fluorescence of aliquot 1- the fluorescence of aliquot 3). Calcein AM penetrates the cytoplasm and organelles including the mitochondria. $\mathrm{CoCl}_{2}$ quenches Calcein AM fluorescence in the cytoplasm but not in the mitochondria. Calcein AM translocates to the cytoplasm from the mitochondria when the mPTP is opened, and the fluorescence is attenuated by $\mathrm{CoCl}_{2}$.

\section{Isolation of cell mitochondria and cytoplasm}

SGC7901 cells were plated into 100-mm plates; each group was plated into two plates. After achieving $60 \%-70 \%$ confluence, the cells were treated with or without $20 \mu \mathrm{mol} / \mathrm{L}$ G503 for $18 \mathrm{~h}$. After treatment, the mitochondrial and cytoplasmic fractions were 
A

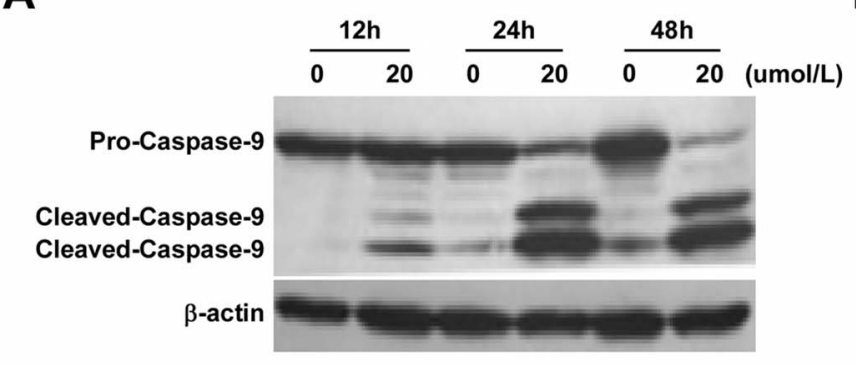

B

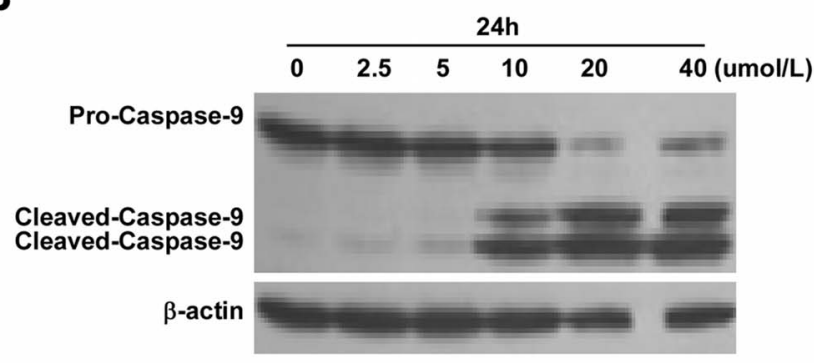

C
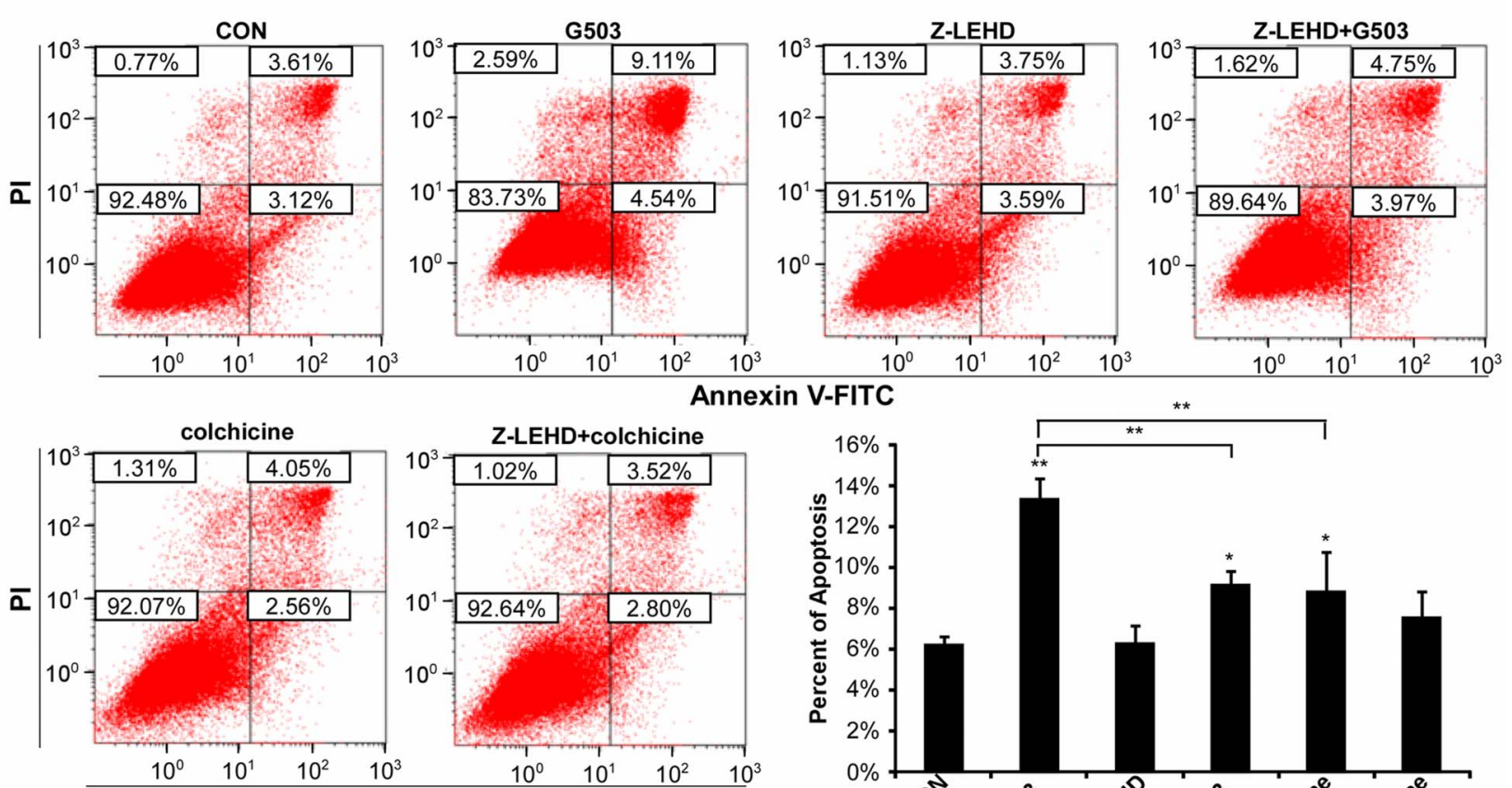

Annexin V-FITC

Annexin V-FITC

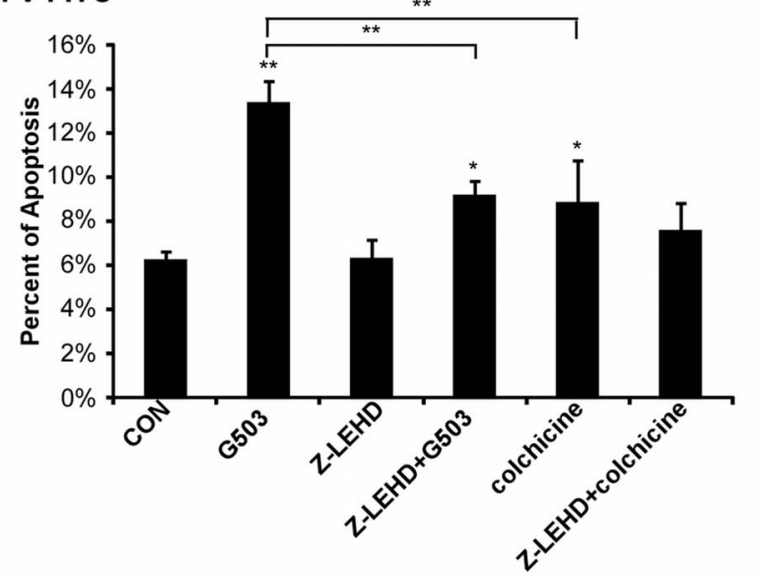

Figure 4. The relationship between caspase-9 and G503-induced apoptosis in SGC7901 cells. (A),(B) Cells were treated with 20 $\mu$ mol/L $\mathrm{G} 503$ for various times (A) and treated with various concentrations of $\mathrm{G} 503$ for $24 \mathrm{~h}$ (B). Cellular proteins were ectracted and caspase-9 protein levels were analyzed by Western blotting. (C) Cells were pre-incubated with Z-LEHD-FMK for 30 min followed by $20 \mu \mathrm{mol} / \mathrm{L}$ G503 for $24 \mathrm{~h}$. The cellular apoptotic rate was detected by flow cytometry. All values are presented as the mean \pm SD of at least three independent experiments. *and ${ }^{* *}$ denote $P<0.05$ and $P<0.01$, respectively.

doi:10.1371/journal.pone.0108286.g004

obtained according to the manufacturer's instructions (Mitochondria isolation kit).

\section{Western blotting analysis}

As described previously, the cells were lysed in RIPA buffer [21]. The protein concentrations of the mitochondria, cytoplasm and whole-cell were detected by the BCA method using the BioRad protein assay kit. In total, $60 \mu \mathrm{g}$ proteins from each group were separated by $12 \%$ or $15 \%$ sodium dodecylsulfate-polyacrylamide gel electrophoresis (SDS-PAGE). The proteins from SDSPAGE were transferred to a PVDF membrane. After the nonspecific binding sites of the membranes were blocked for 1$2 \mathrm{~h}$ at room temperature with TBST buffer containing 10\% nonfat milk, the membranes were incubated overnight at $4^{\circ} \mathrm{C}$ with primary antibody according to the manufacturer's instructions. The secondary antibodies with or without fluorescence conjugated to the relevant primary antibodies were incubated for $2 \mathrm{~h}$ at room temperature. The membranes with fluorescent secondary antibodies were assessed using the Odyssey system (Li-COR, Nebraska,USA) to scan the fluorescent bands [22], and the membranes with normal secondary antibodies were visualized using the ECL detection kit for immunoblots. The membranes were stripped and re-probed with $\beta$-actin or COXIV antibodies. $\beta$-actin was used as the internal standard for the total cell lysate and cytoplasmic extractions, whereas COXIV was used as the control for the mitochondrial extractions. Densitometric analysis of bands was performed using Quantity One (Bio-Rad, Hercules, CA, USA) [23].

\section{Statistical analysis}

All data were presented as means \pm SD at least triplicate determinations. SPSS 13.0 software was used for Student's t-test 
A
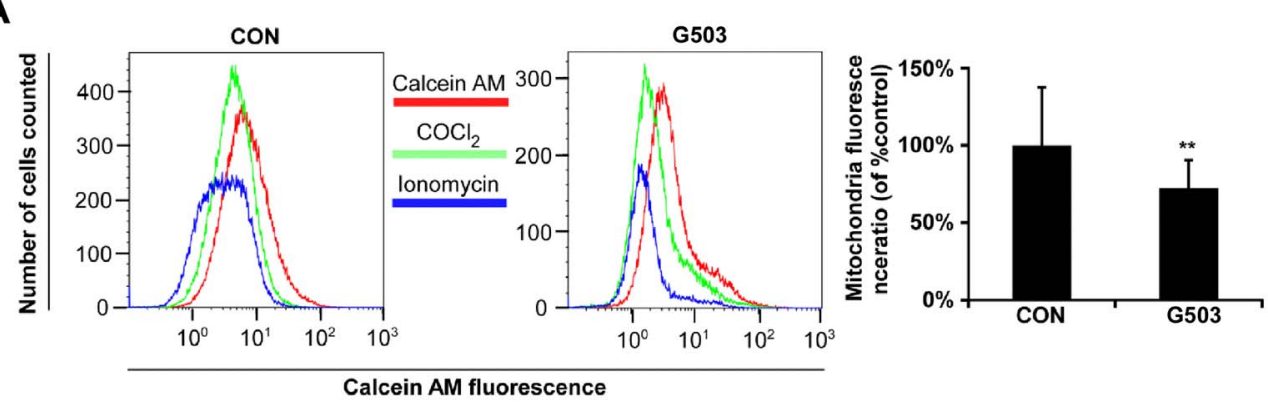

B
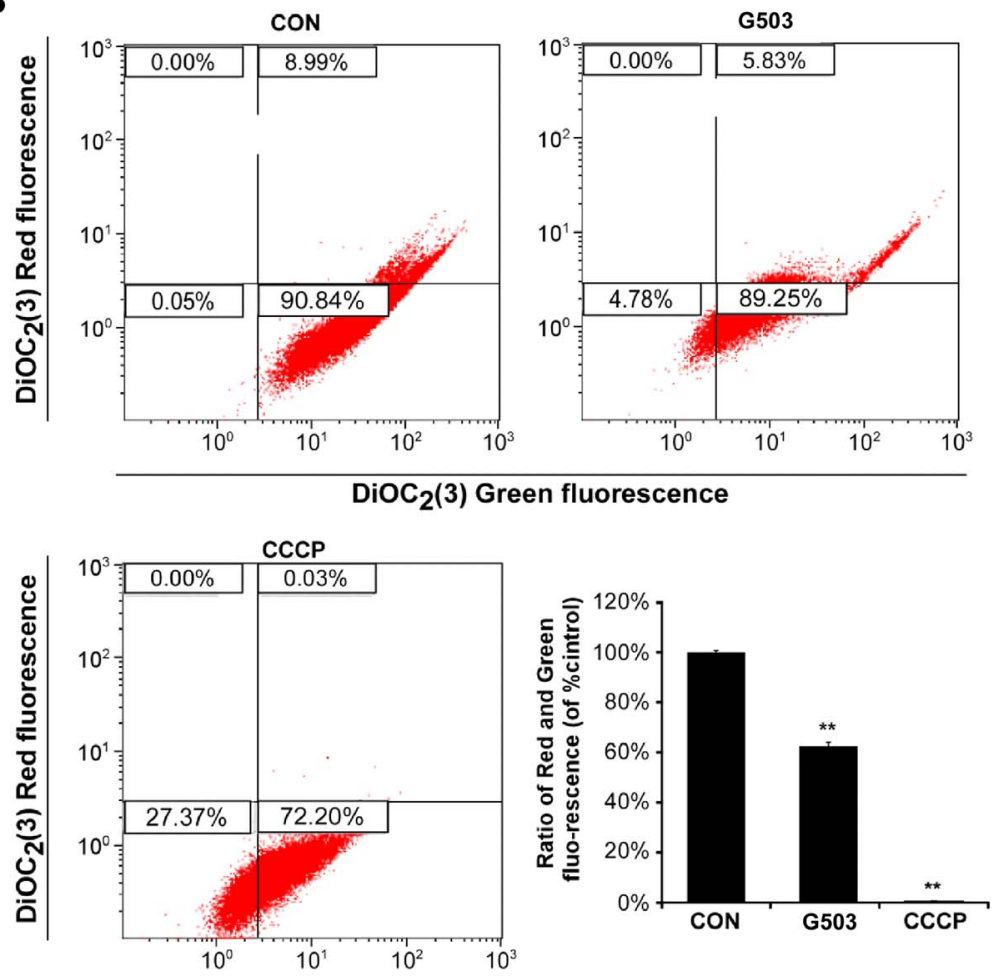

$\overline{\mathrm{DiOC}}_{2}(3)$ Green fluorescence

C

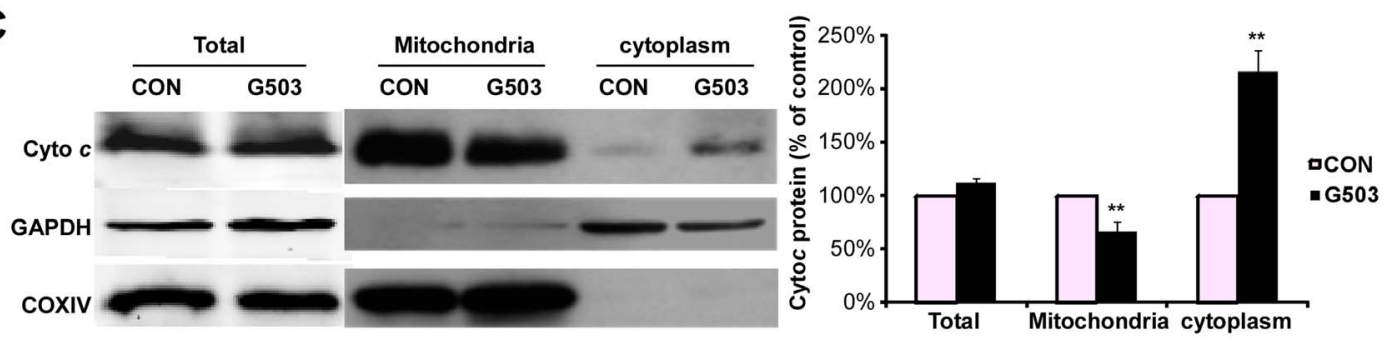

D
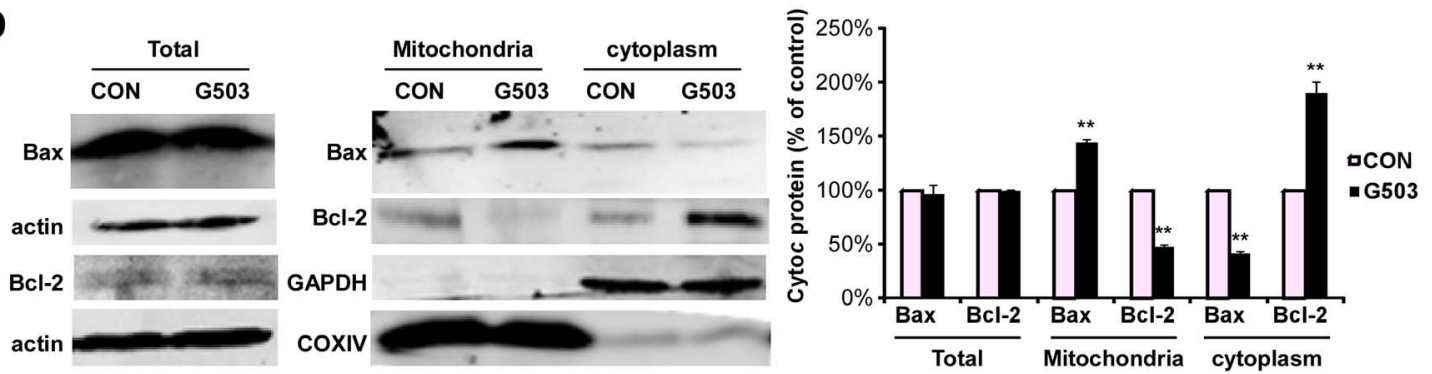
Figure 5. G503 promotes the activation of the mitochondrial apoptotic pathway in SGC7901 cells. (A) Cells were treated with $20 \mu \mathrm{mol} / \mathrm{L}$ G503 for $18 \mathrm{~h}$, and mPTP opening was detected using the mitochondrial membrane permeability fluorescence dye Calcein AM and flow cytometry. (B) Cells were treated with $20 \mu \mathrm{mol} / \mathrm{L} \mathrm{G503}$ for $18 \mathrm{~h}$, and the membrane potential was detected using flow cytometry. "CCCP" is the positive control reagent in the assay kit. (C), (D) Cells were treated with G503 for $18 \mathrm{~h}$. Total protein extracts were collected for Western blotting to assess the levels of Cyto $c(C)$ and $\mathrm{Bax} / \mathrm{BCl}-2$ (D) in the total protein, mitochondrial and cytoplasmic fractions. All values are presented as the mean $\pm S D$ of at least three independent experiments $\left({ }^{*} P<0.05, * * P<0.01\right.$ vs. control).

doi:10.1371/journal.pone.0108286.g005

and one-way analysis of variance (ANOVA) in all statistical analyses. A $P$ value 0.05 was considered statistically significant in all cases.

\section{Results}

G503-mediated inhibition on proliferation is the most potent in SGC7901 cells among the 11 cell lines examined

We used the MTT assay to determine whether the anthraquinone compound G503 is cytotoxic in the following cell lines: two normal cell lines (Human umbilical vein endothelial cells (HUVECs) and Chang liver cells and nine tumor cell lines (HONE-1, GNE-2, 5-8F, HepG2, B7402, Rb, PC3, A549 and SGC7901). All cells were incubated with $0,2.5,5,10,20$ or $40 \mu \mathrm{mol} / \mathrm{L} \mathrm{G503}$ for $48 \mathrm{~h}$. Cell viabilities were measured using the MTT assay as noted, and the $\mathrm{IC}_{50}$ value for SGC7901 cells was the lowest, whereas the $\mathrm{IC}_{50}$ values for the normal cell lines, HUVEC and Chang liver cells, were significantly greater than SGC7901 (Table 1).

\section{G503 induces apoptosis in SGC7901 and AGS gastric cancer cells}

Given that the SGC7901 cell line was the most sensitive to G503 of the eleven cell lines examined (Table 1), we further investigated this cell line separately. SGC7901 cells were stained with Hoechst 33342 to determine whether the inhibitory effect was related to apoptosis. The results indicate an increase in the number of cells displaying nuclear shrinkage and chromatin condensation with increasing G503 concentrations (Figure 1A). In addition, to investigate whether G503 induces apoptosis in other gastric cancer cell lines, AGS gastric cancer cells were also examined. Annexin V/PI staining was employed to analyze the effects of G503 in SGG7901 and AGS gastric cancer cells by flow cytometry. For these experiments, $25 \mu \mathrm{mol} / \mathrm{L}$ colchicine was used as positive control. After treatment with $0 \mu \mathrm{mol} / \mathrm{L}, 2.5 \mu \mathrm{mol} / \mathrm{L}$, $5 \mu \mathrm{mol} / \mathrm{L}, 10 \mu \mathrm{mol} / \mathrm{L}, 20 \mu \mathrm{mol} / \mathrm{L}$ and $40 \mu \mathrm{mol} / \mathrm{L}$ G503 and $25 \mu \mathrm{mol} / \mathrm{L}$ colchicines for $24 \mathrm{~h}$, the percentage of apoptotic
SGC7901 cells were $5.625 \% \pm 0.50 \%, 6.19 \% \pm 0.13 \%, 10.25 \%$ $\pm 0.47 \%, 16.99 \% \pm 1.73 \%, 25.72 \% \pm 0.55 \%, 31.03 \pm 1.03 \%$ and $20.69 \% \pm 1.91 \%$, respectively (Figure 1B); the percentage of apoptotic AGS cells were $15.37 \% \pm 2.36 \%, 19.30 \% \pm 4.45 \%$, $22.72 \% \pm 4.89 \%, 24.93 \% \pm 4.76 \%, 30.44 \% \pm 9.42 \%, 47.51 \%$ $\pm 18.29 \%$ and $31.49 \% \pm 2.45 \%$, respectively (Figure $1 \mathrm{C}$ ). The detection of apoptosis in AGS cells and the above results indicated that G503 induces gastric cancer cell apoptosis in a dosedependent manner.

G503 induces apoptosis in a caspase-dependent manner

To further investigate the mechanism involved in G503-induced apoptosis in gastric cancer cells, we studied SGC7901 cells. Caspase- 3 is an effector caspase that can enter nucleus and directly interact with its substrate, thereby promoting cell apoptosis [24]. Caspse-9 is the initiator caspase that activates caspse-3 [25]. The cells were treated with various G503 concentrations for indicated times and collected to assess caspase- 3 and -9 by Western blotting. The expression of the caspase- 3 precursor decreased in a doseand time-dependent manner, whereas caspase-3 cleavage fragments increased in a dose- and time-dependent fashion (Figure $2 \mathrm{~A}, \mathrm{~B})$. The expression of the caspase-9 precursor also decreased and the cleavage fragments increased after the cells were treated with $20 \mu \mathrm{mol} / \mathrm{L} \mathrm{G503}$ for $24 \mathrm{~h}$ (Figure 2C). These effects are abolished by the pan-caspase inhibitor Z-VAD-FMK (Figure 2C, D). Consistent with the activation of caspase-9 and -3, the apoptotic cell rates induced induced by $20 \mu \mathrm{mol} / \mathrm{L}$ G503 in SGC7901 cells were markedly reduced after pretreatment with ZVAD-FMK (Figure 2E). These data suggested that G503 induces apoptosis in SGC7901 cells in a caspase-dependent manner.

G503-induced apoptosis is not dependent on caspase-8

To investigate whether the death receptor-mediated apoptotic pathway is induced by G503, we studied caspase-8, the initiator caspase of the death receptor-mediated apoptotic pathway [26]. SGC7901 cells were treated with different doses of G503 for indicated times. The cells were collected to measure caspase- 8 by Western blotting. The results indicated that caspase-8 precursor
A

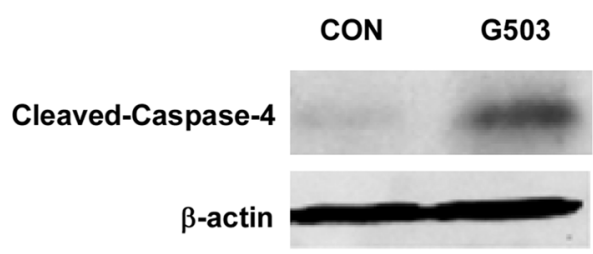

B

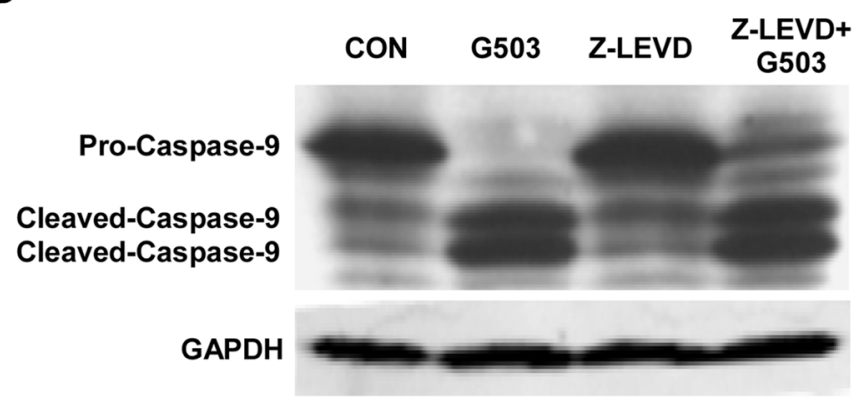

Figure 6. The relationship between caspase-4 and G503-induced apoptosis in SGC7901 cells. (A) Cells were treated with $20 \mu \mathrm{mol} / \mathrm{L}$ G503 for $24 \mathrm{~h}$, and total protein extracts were collected for Western blotting. (B) SGC7901 cells were pre-incubated with $20 \mu \mathrm{mol} / \mathrm{L}$ Z-LEVD-FMK for 30 min followed by $20 \mu \mathrm{mol} / \mathrm{L} \mathrm{G503}$ for $24 \mathrm{~h}$. The cellular protein extracts were used to detect caspase-9 levels by Western blotting. doi:10.1371/journal.pone.0108286.g006 




Figure 7. A Schematic representation of the major molecular mechanisms of G503-induced apoptosis. doi:10.1371/journal.pone.0108286.g007

decreased and cleaved caspase- 8 increased in a time- and dosedependent manner (Figure 3A, B). The cells were pre-treated with $20 \mu \mathrm{mol} / \mathrm{L}$ caspase-8 inhibitor Z-IETD-FMK for $30 \mathrm{~min}$ and then treated with $20 \mu \mathrm{mol} / \mathrm{L}$ G503 for $24 \mathrm{~h}$. The caspase- 8 proform increased in cells co-treated with the caspase-8 inhibitor and G503 compared with cells treated with G503 only. However, the caspase- 9 proform, cleaved caspase- 9 and the caspase- 3 were maintained at similar levels in cells treated with the caspase-8 inhibitor and G503 or G503 alone (Figure 3C). Consistent with Figure 3C, G503-induced apoptotic cell rates in SGC7901 cells were not reduced by pretreatment with Z-IETD-FMK (Figure 3D). These data suggested that despite of activation by G503, caspase-8 is not involved in pro-apoptotic activity of G503.

\section{G503-induced apoptosis is dependent on caspase-9}

Caspase-9, the initiator caspase of the mitochondrial apoptotic pathway, can be activated by combining with cytochrome $c$ (Cyto c) and apoptotic protease-activating factor-1 (Apaf-1) [25-26]. To further investigate whether the mitochondrial pathway is involved in G503-induced apoptosis, the activation of caspase-9 was examined after G503 treatment at various concentrations and times. In addition, the apoptotic cell rate was also measured upon co-treatment with G503 and caspase-9 inhibitor Z-LEHD-FMK. The results indicated that the caspase- 9 proform decreased and the cleavage fragments increased in a time- and dose-dependent manner (Figure 4A, B). Next, the cells were pre-treated with $20 \mu \mathrm{mol} / \mathrm{L}$ Z-LEHD-FMK for $30 \mathrm{~min}$ and co-incubated with $20 \mu \mathrm{mol} / \mathrm{L} \mathrm{G503}$ for $24 \mathrm{~h}$. To quantify the apoptotic cells, the cells were stained with AnnexinV/PI and analyzed by flow cytometry. The results indicated that the apoptotic cell rate decreased when the cells were co-treated with Z-LEHD-FMK and G503 (Figure 4C). Taken together, these data indicated that G503-induced SGC7901 cell apoptosis is dependent on caspase-9 activation.

\section{G503 induces apoptosis via the mitochondrial apoptotic pathway}

It is well known that the mitochondrial pathway is an important apoptotic pathway. To investigate whether G503 induces apoptosis via the mitochondrial pathway, we examined apoptosis-related proteins, the mitochondrial membrane potential (MMP), and the opening of mPTP to confirm the induction of the mitochondrial apoptotic pathway. Follow by G503 treatment, mitochondrial fluorescence decreased compared with control group (Figure 5A), thereby suggesting that the mPTP was opened by G503. Moreover, as shown in Figure 5B, considerable red/green fluorescence intensity was observed in the control group. However, after treatment with $20 \mu \mathrm{mol} / \mathrm{L}$ G503, the red/green fluorescence intensity was reduced. This result suggested that G503 decreases the mitochondrial membrane potential of SGC7901 cells. In addition, total Cyto $c$ protein levels did not notably change between the control and drug group; however, Cyto $c$ was relocalized to the cytoplasm from the mitochondria (Figure 5C). Bax and Bcl-2 are crucial factors in the regulation of mitochondrial channels and the release of various apoptosis-related proteins [27]. Therefore, We studied the distribution of Bax and Bcl-2 in 
different cellular compartments and did not observe a prominent change in the total protein levels of Bax and Bcl-2 between the control and drug group; however, G503 promoted the translocation of Bax from the cytoplasm to the mitochondria as well as the translocation of Bcl-2 from the mitochondria to the cytoplasm (Figure 5D). Taken together, G503 induces apoptosis in SGC7901 cells via the mitochondrial pathway.

\section{G503 induces apoptosis in SGC7901 cells in part through caspase- 4 activation}

Caspase- 4 can directly activate caspase- 9 but not through the mitochondrial pathway [28-29]. To investigate whether caspase-4 is activated by G503 and whether activated caspase- 4 activates caspase-9, we examined the cleavage fragments of caspase- 4 and 9. The results indicated that the caspase- 4 cleavage fragment increased significantly in cells treated with G503 compared with the control group (Figure 6A). Treatment with the caspase-4 inhibitor Z-LEVD-FMK increased the caspase-9 proform, which was not detected in the G503 treatment group (Figure 6B). These results indicated that G503 induces SGC7901 gastric cancer cell apoptosis in part through the activation of caspase- 4 .

\section{Discussion}

It is reported that $p$-quinone moiety of quinone-containing molecular plays an very important role in anti-cancer potential [30]. Perchellet et al. also found that p-quinone J4, o-quinone J1 and unsubstituted model p-quinone $\mathrm{J} 7$ reduced the most L1210 tumor cell viability among eight compounds synthesized and screened in their preliminary study [31]. To understand the relationship between the anti-cancer potential of altersolanol $\mathrm{A}$ and structure-activity, Teiten et al. evaluated the effect of altersolanol $\mathrm{A}$ and its related anthracene derivatives: tetraacetylaltersolanol A, tetrahydroaltersolanol B and ampelanol. They found that only altersolanol $\mathrm{A}$ and its acetylated derivative tetraacetylaltersolanol A present a cytotoxic effect on K562 cells, whereas derivatives with reduction of one of the carbonyl groups, such as tetrahydroaltersolanol B and ampelanol, have no effect [32]. The $p$-quinone structure of G503 (Figure S1) may also be contributed to cancer cell apoptosis, and in the next research we will analyze the G503 and its derivatives to identify the preliminary structure-activity relationship. In this study, we find that the gastric cancer cell line SGC7901 is the most G503sensitive cancer cell line examined using a cell viability assay in nine cancer cell lines and two normal cell lines. G503 induces SGC7901 gastric cancer cell death via apoptosis in a dosedependent manner. Another gastric cancer cells AGS is also examined, and is sensitive to G503-induced apoptosis as well. As a result, $20 \mu \mathrm{mol} / \mathrm{L}$ G503 is the optimum concentration that induces severe apoptosis.

The human genome encodes at least 10 types of caspase homologs. The following caspase homologs participate in apoptosis: Caspase-2, -3, -8, -9 and -10 [33]. Although caspases play a role in apoptosis, there are various caspase independent pathways exist. For example, in the presence of caspase inhibitors, tumor necrosis factor (TNF) induces cell necrosis, which possesses the characteristics of apoptosis and necrosis [34-36]. In addition, apoptosis-inducing factor (AIF) is a DNA enzyme that directly degrades DNA. When the mitochondrial membrane potential is altered, AIF is released to the cytoplasm from the mitochondria and is activated by its interaction with cyclophilinA [37-38]. Endo $\mathrm{G}$ can also degrade DNA directly in a caspase-independent manner [39].
In our study, G503 exposure activates caspase- $3,-8$ and -9 in a dose- and time-dependent manner (Figure 2A, B; 3A, B; 4A, B). Is G503-induced apoptosis dependent on caspases? When cells were co-treated with Z-VAD-FMK and G503, Z-VAD-FMK inhibits caspase-9 and -3 activation (Figure 2C, D), and the number of apoptotic cells induced by G503 decreased (Figure 2E), thereby indicating that G503-induced SGC7901 cell apoptosis is caspasedependent. To distinguish whether G503-induced apoptosis is dependent on caspase-8, -9 or both, SGC7901 cells were pretreated with Z-IETD-FMK and Z-LEHD-FMK and then cotreated with G503. The results indicate that Z-IETD-FMK do not inhibit caspase-9 and -3 activation (Figure $3 \mathrm{C}$ ) nor decrease the number of apoptotic cells induced by G503 (Figure 3D); however, Z-LEHD-FMK decreased the number of apoptotic cells (Figure 4C). Thus, G503-induced SGC7901 cell apoptosis is not dependent on caspase-8 but is on caspase- 9 .

The mitochondria consist of an outer membrane, membrane space and matrix. Apoptosis-related proteins, such as caspase proenzymes, Cyto $c$ and AIF exist in the membrane space. However, when pores formed in the outer mitochondrial membrane or the permeability is altered, these apoptosis-related proteins are released to the cytoplasm. Members of the Bcl-2 family control the permeability of the outer mitochondrial membrane, and can be divided into two members that promote apoptosis (such as Bax and Bak) or inhibit apoptosis (such as Bcl-2 and $\mathrm{Bcl}-\mathrm{xL}$ ). The pro-apoptotic members promote the release of apoptosis-related proteins, such as Cyto $c$, from the mitochondria, whereas the anti-apoptotic members have an opposite effect [40]. Bax primarily exists in the cytoplasm, whereas Bcl-2 combines with hydrophobic groups at the C-terminal of the cell's biomembrane [41]. Bax structure is altered during external stress so that it combines with the outer mitochondrial membrane tospontaneously form a gallery by homologous oligomerization. This action induces the release of apoptosis-related proteins [42] or the formation of the mitochondria Permeability Transition Pore (mPTP), which consists of voltage-dependent anion channel (VDAC) on the outer mitochondrial membrane and adenine nucleotide translocator (ANT) on the inner membrane [43]. Bax only interacts with VDAC to create an open pore when Bax concentrations are low. In contrast, Bax simultaneously interacts with VDAC and ANT when Bax concentrations are high to open the pores in the inner and outer membrane. This action reduces the inner membrane potential, increases the osmotic pressure of the mitochondrial matrix, promotes inner membrane swelling and increases the osmotic pressure of the outer membrane, thereby promoting the release of apoptosis-related proteins [26,44 46]. An important step in the mitochondrial apoptotic pathway is the release of Cyto $c$ [47-49]. Cyto $c$ combines with Apaf-1 and the caspase- 9 proform to create the apoptosome. Apaf-1 exposes its oligomerization domain, and the N-terminal Caspase activation and recruitment domains (CARD) combines with the caspase-9 proform CARD. Thus, caspase- 9 is activated, and the activated caspase-9 cleaves downstream caspases, such as caspse- 3 and -7 . The effector caspases eventually cleave their corresponding substrates to induce cell apoptosis $[47,49-50]$.

In this study, G503 increases the proportion of Bax/Bcl-2 on the mitochondrial membrane and decreases the $\mathrm{Bax} / \mathrm{Bcl}-2$ ratio in the cytoplasm (Figure 5D). G503 also promotes mPTP opening and the reduction of the mitochondrial membrane potential (Figure 5A, B). Then, Cyto $c$ was transferred from the mitochondria to the cytoplasm (Figure 5C). In addition, G503 promotes the transfer of Bax to the mitochondria from the cytoplasm and Bcl-2 to the cytoplasm from the mitochondria. Increased Bax and reduced Bcl-2 in the mitochondria increase the permeation of the 
mitochondrial outer membrane and promote the release of Cyto $c$. The regulation of Bax/Bcl-2 by G503 may be observed because G503 is a small molecular compound. It is possible that G503 directly enters cells and combines with Bax and Bcl-2 to alter their structures, thereby causing Bax binding to the outer mitochondrial membrane and Bcl-2 release from the mitochondria.

Several studies have shown that ROS generation is essential for anthraquinone-induced apoptosis in cancer cells [51-52]. ROS is a potent inducer of oxidation injury that can result in base pairs oxidation as well as depurinated and aldehydic DNA [44,46,48], despite this injury can be counter balanced by antioxidants, whose expression are mediated by Toll pathway through ROS evaluation [53]. ROS also participate in the regulation of special cell functions, such as apoptosis [54]. ROS regulate p38 Mitogenactivated protein kinases (MAPK) phosphorylation to activate cellular apoptosis [55-57]. After activating MAPKKKs, such as Apoptosis signal-regulating kinase 1 (ASK1), ROS continue to phosphorylate downstream MKK3/6 to activate p38 MAPK [51]. Phosphorylated p38 MAPK then activates the mitochondrial apoptotic pathway to induce apoptosis $[27,58]$. In this study, we observed that G503 enhances the ROS levels in SGC7901 cells in a time- and dose-dependent manner (Figure S2A); however, the ROS scavenger NAC do not inhibit G503-induced activation of caspase-9 and-3 as well as subsequent apoptosis (Figure S2B, C, D). Moreover, G503 increases the level of p-p38 MAPK in a timeand dose-dependent manner (Figure S3A, B). Nevertheless, NAC did not reverse p38 MAPK up-regulation induced by G503 (Figure S3C). In addition, the p38 MAPK inhibitor SB203580 do not inhibit G503-induced activation of caspase-9 and -3 nor apoptosis (Figure S3D, E, F). Although G503 promotes the generation of ROS and activates p38 MAPK, these factors are not involved in G503-induced apoptosis. G503-induced SGG7901 gastric cancer cell apoptosis is not dependent on the ROS-p38 MAPK pathway.

Caspase-9 is most commonly activated when Cyto $c$, Apaf- 1 and the caspase- 9 proenzyme form a complex. In addition, caspase- 4 also directly activates caspase-9 via the mitochondria [29,59]. Caspase- 4 is an inflammation caspase of the Caspase- 1 family that localizes to the endoplasmic reticulum(ER). Bian et al. found that the induction of ER stress by tunicamycin and thapsigargin increases the expression of caspase- $4 \mathrm{mRNA}$ and activation of caspase-4 [60]. In addition, Yamamuro et al. found that caspase-4 directly cleaves the caspase-9 proform at ASP-315, which is the site cleaved by the apoptosome in the mitochondrial apoptotic pathway [29]. In our study, G503 clearly activates caspase-4 (Figure 6A), and caspase-9 cleavage was not completely inhibited by the caspase- 4 inhibitor Z-LEVD-FMK; the cleavage fragments of Caspase- 9 remained the same, whereas the caspase- 9 proform exclusively increased (Figure $6 \mathrm{~B}$ ). This result may be attributed to the fact that G503 activates caspase-9 primarily through the mitochondrial apoptotic pathway, and caspase- 4 mediated activation of caspase-9 plays a small part role in G503-induced apoptosis.

In conclusion, G503, a secondary metabolite of marine microorganisms, is a potent inducer of apoptosis in SGC7901 and AGS gastric cancer cells. G503 induces apoptosis in SGC7901 gastric cancer cells primarily through the mitochondrial apoptotic pathway and partly through the activation of caspase- 4 in the endoplasmic reticulum (Figure 7). G503 research suggests that it is a lead compound for the treatment of gastric cancer.

\section{Supporting Information}

Figure S1 Ghemical structure of G503 (MW: 320). (TIF)

Figure S2 G503 induces SGC7901 cells apoptosis in an ROS-independent manner. (A) SGC7901 cells were treated with $20 \mu \mathrm{mol} / \mathrm{L}$ G503 for $0,4,12$, or $24 \mathrm{~h}$ or various concentrations of G503 (0-40 $\mu \mathrm{mol} / \mathrm{L})$ for $12 \mathrm{~h}$. After treatment, ROS was measured using carboxy-H2DCFDA and flow cytometry. ROS generation increased as time and concentration increased. (B-C) SGC7901 cells were pre-incubated with $5 \mathrm{mmol} / \mathrm{L} \mathrm{NAG}$ for $2 \mathrm{~h}$ to prevent ROS generation and then treated with $20 \mu \mathrm{mol} / \mathrm{L}$ G503 for $24 \mathrm{~h}$. The cells were collected, and the total protein extracts were used to detect the levels of the proform and cleaved fragments of caspase- 9 and -3 by Western blotting. (D) SGC7901 cells were pre-incubated with $5 \mathrm{mmol} / \mathrm{L}$ NAC for $2 \mathrm{~h}$ to prevent the generation of ROS and then treated with $20 \mu \mathrm{mol} / \mathrm{L}$ G503 for $24 \mathrm{~h}$. The apoptotic cell rate was detected by AnnexinV/PI and flow cytometry. All values are displayed as the mean $\pm \mathrm{SD}$ of at least three independent experiments; * and ** denote $\mathrm{p}<0.05$ and $\mathrm{p}<0.01$, respectively. (TIF)

Figure S3 G503 induces SGG7901 cell apoptosis in a p38 MAPK-independent manner. (A) SGC7901 cells were treated with $20 \mu \mathrm{mol} / \mathrm{L} \mathrm{G503}$ for various times $(0.5,6,12$, or $24 \mathrm{~h})$. The cells were collected, and the total protein extracts were used to detect p38 MAPK and p-p38 MAPK levels by Western blotting. The same membrane was stripped and incubated with an antibody against $\beta$-actin for normalization. (B) SGC7901 cells were treated with $\mathrm{G} 503$ at various concentrations $(0-40 \mu \mathrm{mol} / \mathrm{L})$ for $24 \mathrm{~h}$. The cells were collected, and the total protein extracts were used to detect p38 MAPK and p-p38 MAPK levels by Western blotting as described in Figure S2A. (C) SGC7901 cells were pre-treated with $5 \mathrm{mmol} / \mathrm{L} \mathrm{NAC}$ for $2 \mathrm{~h}$ to prevent ROS generation and then treated with $20 \mu \mathrm{mol} / \mathrm{L}$ G503 for $6 \mathrm{~h}$. The cells were collected, and the p38 and p-p38 levels were assessed by Western blotting. (D-E) SGC7901 cells were pre-incubated with $10 \mu \mathrm{mol} / \mathrm{L}$ of the p38 MAPK inhibitor (SB203580) for $1 \mathrm{~h}$ and then treated with $20 \mu \mathrm{mol} / \mathrm{L}$ G503 for $24 \mathrm{~h}$. The cells were collected, and the total protein extracts were used to detect caspase- 9 and -3 levels by Western blotting. (F) The cells were preincubated with the p38 MAPK inhibitor (SB203580) for $1 \mathrm{~h}$ and then treated with $20 \mu \mathrm{mol} / \mathrm{L}$ G503 for $24 \mathrm{~h}$. The apoptotic cell rate was determined by Annexin V/PI and flow cytometry. All values are displayed as the mean $\pm \mathrm{SD}$ of at least three independent experiments $\left(* \mathrm{P}<0.05,{ }^{*} \mathrm{P}<0.01\right.$ vs. control).

(TIF)

File S1 G503 induces apoptosis in a ROS-MAPK-independent manner.

(DOC)

\section{Acknowledgments}

We thank the Doctor. Zhiyu Dai and Zhenwei Liang for English language editing of the manuscript.

\section{Author Contributions}

Conceived and designed the experiments: XY GG. Performed the experiments: LH TZ SL JD FY. Analyzed the data: LH TZ. Contributed reagents/materials/analysis tools: HL ZS. Contributed to the writing of the manuscript: LH TZ. 


\section{References}

1. PharmD CW (2007) Ethnopharmacology of Medicinal Plants:Aisa and the Pacific. In: Plants for Chemotherapy of Neoplastic Diseases. New Jersey: Humana Press. 155-217.

2. Weiss RB (1992) The anthracyclines: will we ever find a better doxorubicin? Semin Oncol 19: 670-686.

3. Cooper EL (2004) Drug Discovery, CAM and Natural Products. Evid Based Complement Alternat Med 1: 215-217.

4. Banerjee S, Wang Z, Mohammad M, Sarkar FH, Mohammad RM (2008) Efficacy of selected natural products as therapeutic agents against cancer. Journal of Natural Products 71: 492-496.

5. Xie G, Zhu X, Li Q, Gu M, He Z, et al. (2010) SZ-685C, a marine anthraquinone, is a potent inducer of apoptosis with anticancer activity by suppression of the Akt/FOXO pathway. Br J Pharmacol 159: 689-697.

6. Zhu X, He Z, Wu J, Yuan J, Wen W, et al. (2012) A marine anthraquinone SZ$685 \mathrm{C}$ overrides adriamycin-resistance in breast cancer cells through suppressing Akt signaling. Mar Drugs 10: 694-711.

7. Wang D, Wang S, Liu Q, Wang M, Wang C, et al. (2013) SZ-685C exhibits potent anticancer activity in both radiosensitive and radioresistant NPC cells through the miR-205-PTEN-Akt pathway. Oncol Rep 29: 2341-2347.

8. Huang Q, Lu G, Shen HM, Chung MC, Ong CN (2007) Anti-cancer properties of anthraquinones from rhubarb. Med Res Rev 27: 609-630.

9. Gewirtz DA (1999) A critical evaluation of the mechanisms of action proposed for the antitumor effects of the anthracycline antibiotics adriamycin and daunorubicin. Biochem Pharmacol 57: 727-741.

10. Minotti G, Menna P, Salvatorelli E, Cairo G, Gianni L (2004) Anthracyclines: molecular advances and pharmacologic developments in antitumor activity and cardiotoxicity. Pharmacol Rev 56: 185-229.

11. Laurent G, Jaffrezou JP (2001) Signaling pathways activated by daunorubicin. Blood 98: 913-924.

12. Martin D, Salinas M, Fujita N, Tsuruo T, Guadrado A (2002) Ceramide and reactive oxygen species generated by $\mathrm{H} 2 \mathrm{O} 2$ induce caspase-3-independent degradation of Akt/protein kinase B. J Biol Chem 277: 42943-42952.

13. Clementi ME, Giardina B, Di Stasio E, Mordente A, Misiti F (2003) Doxorubicin-derived metabolites induce release of cytochrome $\mathrm{C}$ and inhibition of respiration on cardiac isolated mitochondria. Anticancer Res 23: 2445-2450.

14. Perchellet EM, Wang Y, Weber RL, Sperfslage BJ, Lou K, et al. (2004) Synthetic 1,4-anthracenedione analogs induce cytochrome c release, caspase-9, 3 , and -8 activities, poly(ADP-ribose) polymerase-1 cleavage and internucleosomal DNA fragmentation in HL-60 cells by a mechanism which involves caspase-2 activation but not Fas signaling. Biochem Pharmacol 67: 523-537.

15. She ZG, Lin YC, Huang HR, Xia XK, Cai XL, et al. (2008) Quinones preparation method and anti-tumor application. Chinese Patent Application No.200510037139.4

16. Folkman J (2007) Angiogenesis: an organizing principle for drug discovery? Nat Rev Drug Discov 6: 273-286.

17. Gu X, Yao Y, Cheng R, Zhang Y, Dai Z, et al. (2011) Plasminogen K5 activates mitochondrial apoptosis pathway in endothelial cells by regulating Bak and Bcl$\mathrm{x}(\mathrm{L})$ subcellular distribution. Apoptosis 16: 846-855.

18. Feng D, Ling WH, Duan RD (2010) Lycopene suppresses LPS-induced NO and IL-6 production by inhibiting the activation of ERK, p38MAPK, and NFkappaB in macrophages. Inflamm Res 59: 115-121.

19. Nakase I, Gallis B, Takatani-Nakase T, Oh S, Lacoste E, et al. (2009) Transferrin receptor-dependent cytotoxicity of artemisinin-transferrin conjugates on prostate cancer cells and induction of apoptosis. Cancer Lett 274: 290298.

20. Li R, Wu X, Wei H, Tian SK (2013) Characterization of side population cells isolated from the gastric cancer cell line SGC-7901. Oncol Lett 5: 877-883.

21. Wang Z, Zhang Q Li Y, Li P, Zhang G, et al. (2009) Involvement of mitogenactivated protein kinases and nuclear factor kappa B pathways in signaling COX-2 expression in chronic rhinosinusitis. Inflamm Res 58: 649-658.

22. Wang R, Xie H, Huang Z, Ma J, Fang X, et al. (2011) T cell factor 1 regulates thymocyte survival via a RORgammat-dependent pathway. J Immunol 187: 5964-5973.

23. Blomgran R, Zheng L, Stendahl O (2007) Cathepsin-cleaved Bid promotes apoptosis in human neutrophils via oxidative stress-induced lysosomal membrane permeabilization. J Leukoc Biol 81: 1213-1223.

24. Stennicke HR, Salvesen GS (1998) Properties of the caspases. Biochim Biophys Acta 1387: 17-31.

25. Bratton SB, MacFarlane M, Cain K, Cohen GM (2000) Protein complexes activate distinct caspase cascades in death receptor and stress-induced apoptosis. Exp Cell Res 256: 27-33

26. Pastorino JG, Tafani M, Rothman RJ, Marcinkeviciute A, Hoek JB, et al. (1999) Functional consequences of the sustained or transient activation by Bax of the mitochondrial permeability transition pore. J Biol Chem 274: 31734-31739.

27. Gross A, McDonnell JM, Korsmeyer SJ (1999) BCL-2 family members and the mitochondria in apoptosis. Genes Dev 13: 1899-1911.

28. Kang YH, Lee SJ (2008) Role of p38 MAPK and JNK in enhanced cervical cancer cell killing by the combination of arsenic trioxide and ionizing radiation. Oncol Rep 20: 637-643.
29. Yamamuro A, Kishino T, Ohshima Y, Yoshioka Y, Kimura T, et al, (2011) Caspase-4 directly activates caspase-9 in endoplasmic reticulum stress-induced apoptosis in SH-SY5Y cells. J Pharmacol Sci 115: 239-243.

30. Saify ZS, Mushtaq N, Noor F, Takween S, Arif M (1999) Role of quinone moiety as antitumor agents: a review. Park J Pharm Sci 12: 21-31.

31. Perchellet EM, Sperfslage BJ, Qabaja G, Jones GB,Perchellet JP (2001) Quinone isomers of the WS-5995 antibiotics: synthetic antitumor agents that inhibit macromolecule synthesis, block nucleoside transport, induce DNA fragmentation, and decrease the growth and viability of L1210 leukemic cells more effectively than ellagic acid and genistein in vitro. Anticancer Drugs 12: 401417.

32. Teiten MH, Mack F, Debbab A, Aly AH, Dicato M, et al. (2013) Anticancer effect of altersolanol A, a metabolite produced by the endophytic fungus Stemphylium globuliferum, mediated by its pro-apoptotic and anti-invasive potential via the inhibition of NF- $\mathrm{\kappa B}$ activity. Bioorg Med Chem 21: 38503858

33. Hyman BT, Yuan J (2012) Apoptotic and non-apoptotic roles of caspases in neuronal physiology and pathophysiology. Nat Rev Neurosci 13: 395-406.

34. Cauwels A, Janssen B, Waeytens A, Cuvelier C, Brouckaert P (2003) Caspase inhibition causes hyperacute tumor necrosis factor-induced shock via oxidative stress and phospholipase A2. Nat Immunol 4: 387-393.

35. Susin SA, Lorenzo HK, Zamzami N, Marzo I, Snow BE, et al. (1999) Molecular characterization of mitochondrial apoptosis-inducing factor. Nature 397: 441446.

36. Yuan J, Kroemer G (2010) Alternative cell death mechanisms in development and beyond. Genes Dev 24: 2592-2602.

37. Cregan SP, Dawson VL, Slack RS (2004) Role of AIF in caspase-dependent and caspase-independent cell death. Oncogene 23: 2785-2796.

38. Yu SW, Andrabi SA, Wang H, Kim NS, Poirier GG, et al. (2006) Apoptosisinducing factor mediates poly(ADP-ribose) (PAR) polymer-induced cell death. Proc Natl Acad Sci U S A 103: 18314-18319.

39. Rupinder SK, Gurpreet AK, Manjeet S (2007) Cell suicide and caspases. Vascul Pharmacol 46: 383-393.

40. Desagher S, Martinou JC (2000) Mitochondria as the central control point of apoptosis. Trends Cell Biol 10: 369-377.

41. Hsu YT, Wolter KG, Youle RJ (1997) Cytosol-to-membrane redistribution of Bax and Bcl-X(L) during apoptosis. Proc Natl Acad Sci U S A 94: 3668-3672.

42. Martinou JC, Green DR (2001) Breaking the mitochondrial barrier. Nat Rev Mol Cell Biol 2: 63-67.

43. Zamzami N, Kroemer G (2001) The mitochondrion in apoptosis: how Pandora's box opens. Nat Rev Mol Cell Biol 2: 67-71.

44. Jurgensmeier JM, Xie Z, Deveraux Q Ellerby L, Bredesen D, et al. (1998) Bax directly induces release of cytochrome c from isolated mitochondria. Proc Natl Acad Sci U S A 95: 4997-5002.

45. Marzo I, Brenner C, Zamzami N, Jurgensmeier JM, Susin SA, et al. (1998) Bax and adenine nucleotide translocator cooperate in the mitochondrial control of apoptosis. Science 281: 2027-2031.

46. Narita M, Shimizu S, Ito T, Chittenden T, Lutz RJ, et al. (1998) Bax interacts with the permeability transition pore to induce permeability transition and cytochrome c release in isolated mitochondria. Proc Natl Acad Sci U S A 95: $14681-14686$

47. Aleo E, Henderson CJ, Fontanini A, Solazzo B, Brancolini C (2006) Identification of new compounds that trigger apoptosome-independent caspase activation and apoptosis. Cancer Res 66: 9235-9244.

48. Fuentes-Prior P, Salvesen GS (2004) The protein structures that shape caspase activity, specificity, activation and inhibition. Biochem J 384: 201-232.

49. Gupta S (2003) Molecular signaling in death receptor and mitochondrial pathways of apoptosis (Review). Int J Oncol 22: 15-20.

50. Chowdhury I, Tharakan B, Bhat GK (2006) Current concepts in apoptosis: the physiological suicide program revisited. Cell Mol Biol Lett 11: 506-525.

51. Bolton JL, Trush MA, Penning TM, Dryhurst G, Monks TJ (2000) Role of quinones in toxicology. Chem Res Toxicol 13: 135-160.

52. Wang X, Thomas B, Sachdeva R, Arterburn L, Frye L, et al. (2006) Mechanism of arylating quinone toxicity involving Michael adduct formation and induction of endoplasmic reticulum stress. Proc Natl Acad Sci U S A 103: 3604-3609.

53. Pan X, Zhou G, Wu J, Bian G, Lu P, et al. (2012) Wolbachia induces reactive oxygen species (ROS)-dependent activation of the Toll pathway to control dengue virus in the mosquito Aedes aegypti. Proc Natl Acad Sci U S A 109: E23-31.

54. Danial NN, Korsmeyer SJ (2004) Cell death: critical control points. Cell 116: 205-219.

55. Liu WL, Guo X, Chen QQ, Guo ZG (2002) VEGF protects bovine aortic endothelial cells from TNF-alpha- and $\mathrm{H} 2 \mathrm{O} 2$-induced apoptosis via comodulatory effects on p38-and p42/p44-CCDPK signaling. Acta Pharmacol Sin 23: $45-49$

56. Liu WL, Guo X, Guo ZG (2000) Effects of p38 and p42/p44 CCDPK signaling on $\mathrm{H} 2 \mathrm{O} 2$-induced apoptosis in bovine aortic endothelial cells. Acta Pharmacol Sin 21: 991-996.

57. Mates JM, Segura JA, Alonso FJ, Marquez J (2008) Intracellular redox status and oxidative stress: implications for cell proliferation, apoptosis, and carcinogenesis. Arch Toxicol 82: 273-299. 
58. Selimovic D, Hassan M, Haikel Y, Hengge UR (2008) Taxol-induced mitochondrial stress in melanoma cells is mediated by activation of c-Jun Nterminal kinase (JNK) and p38 pathways via uncoupling protein 2. Cell Signal 20: 311-322.

59. Nicolau-Galmes F, Asumendi A, Alonso-Tejerina E, Perez-Yarza G, Jangi SM, et al. (2011) Terfenadine induces apoptosis and autophagy in melanoma cells through ROS-dependent and -independent mechanisms. Apoptosis 16: 12531267.

60. Bian ZM, Elner SG, Elner VM (2009) Dual involvement of caspase-4 in inflammatory and ER stress-induced apoptotic responses in human retinal pigment epithelial cells. Invest Ophthalmol Vis Sci 50: 6006-6014 